\title{
Metadata Correction: Immune-Enhancing Formulas for Patients With Cancer Undergoing Esophagectomy: Systematic Review Protocol
}

Astrid Naranjo, BNutr \& Diet (Hons), MNutr \& Diet Prac; Elizabeth Isenring, BHSc (Nut \& Diet, Hons 1), PhD; Laisa Teleni, BBiomedSci (Hon), MND

Faculty of Health Sciences and Medicine, Bond University, Gold Coast, Australia

\section{Corresponding Author:}

Astrid Naranjo, BNutr \& Diet (Hons), MNutr \& Diet Prac

Faculty of Health Sciences and Medicine

Bond University

14 University Drive

Robina, QLD

Gold Coast, 4226

Australia

Phone: 61426844919

Fax: 6175595352

Email: a.naranjomartinez@student.bond.edu.au

\section{Related Article:}

Correction of: http://www.researchprotocols.org/2017/11/e214/

(JMIR Res Protoc 2018;7(4):e61) doi: 10.2196/resprot.9615

In the paper by Astrid Naranjo et al, "Immune-Enhancing Formulas for Patients With Cancer Undergoing Esophagectomy: Systematic Review Protocol" (JMIR Res Protoc 2017;6(11):e214), mistakes were made when listing the authors' degrees. Laisa Teleni's highest qualification was incorrectly listed as $\mathrm{PhD}$. The correct degrees for Laisa Teleni are “BBiomedSci (Hon), MND”. Elisabeth Isenring's degrees were incorrectly listed as "BHSc (Nut \& Diet, Hons 1, GradCertHighEd)". The correct degrees for Elisabeth Isenring are "BHSc (Nut \& Diet, Hons 1), PhD". The affiliations of the authors have not been changed.

The corrected article will appear in the online version of the paper on the JMIR website on April 27, 2018, together with the publication of this correction notice. Because this was made after submission to PubMed, Pubmed Central, and other full-text repositories, the corrected article also has been re-submitted to those repositories.

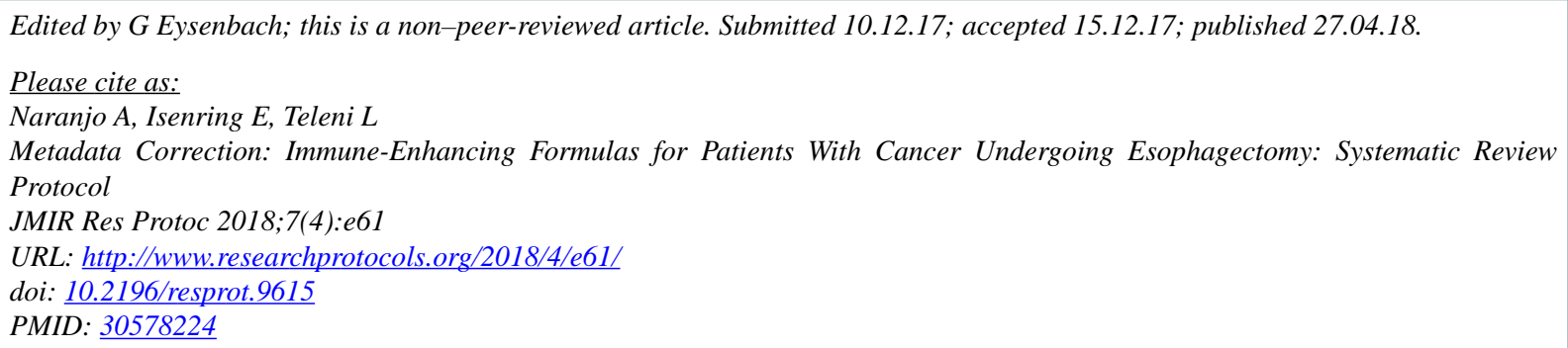

CAstrid Naranjo, Elisabeth Isenring, Laisa Teleni. Originally published in JMIR Research Protocols (http://www.researchprotocols.org), 27.04.2018. This is an open-access article distributed under the terms of the Creative Commons Attribution License (https://creativecommons.org/licenses/by/4.0/), which permits unrestricted use, distribution, and reproduction in any medium, provided the original work, first published in JMIR Research Protocols, is properly cited. The complete bibliographic 
information, a link to the original publication on http://www.researchprotocols.org, as well as this copyright and license information must be included. 